\title{
Entrepreneurial Behaviour in Periods of Deterioration of Small Firms' Condition
}

\author{
Jarosław Ropęga
}

\begin{abstract}
A B S T R A C T
Objective: The aim of the paper is to indicate types of entrepreneurial behaviour which should be triggered during periods of deterioration of small firms' condition.

Research Design \& Methods: The study concerned the causes and symptoms of economic failure identified along the trajectories of this phenomenon. The paper uses selected parts of the study related to the non-occurrence of entrepreneurial behaviour or errors in this behaviour identified in the surveyed firms. The entire study was conducted based on the analysis of 32 case studies carried out among the former entrepreneurs of micro and small firms liquidated in the period from 01.01.2006 to 31.12.2011.
\end{abstract}

Findings: The study helped to identify shortcomings in the entrepreneurial process along individual trajectories of economic failure of the surveyed companies.

Implications \& Recommendations: As a result of the conscious entrepreneurial process, small firms have the opportunity to leave the trajectory of economic failure, indicated by the deteriorating condition of the company. It is therefore necessary to develop knowledge concerning the entrepreneurial process and entrepreneurship among managers of small firms.

Contribution \& Value Added: According to the author, one of the key factors affecting the survival of small businesses in the period of deterioration of their condition is the initiation of the entrepreneurial process and/or its deliberate continuation. It seems quite natural to base components of this process on the existing support tools for entrepreneurs that are at risk of economic failure.

\begin{tabular}{lll}
\hline Article type: & $\begin{array}{l}\text { research paper } \\
\text { entrepreneurial process; economic failure; small firms; entrepreneur- }\end{array}$ \\
Keywords: & $\begin{array}{l}\text { ial behaviour; firm's survival; entrepreneurship; trajectories of eco- } \\
\text { nomic failure }\end{array}$ \\
JEL codes: & L26 & \\
\hline Received: 16 February 2016 & Revised: May 2016 & Accepted: 30 May 2016 \\
\hline
\end{tabular}

\section{Suggested citation:}

Ropęga, J. (2016). Entrepreneurial Behaviour in Periods of Deterioration of Small Firms' Condition. Entrepreneurial Business and Economics Review, 4(2), 139-156, DOI: http://dx.doi.org/10.15678/EBER.2016.040211 


\section{INTRODUCTION}

In today's economy an increasing number of analyses are devoted to observation and evaluation of business growth and development processes. The interest is not focused only on large and medium-sized companies, but also on small and micro firms. The phenomenon of an increasing interest in growth and development processes in the group of micro and small firms provides a great opportunity to identify ways in which entrepreneurial behaviour, or the lack thereof, affects changes occurring within companies. The author of the paper assumes the need for comprehensive perception of entrepreneurial behaviour in this group of firms. However, it is a very difficult task, since, despite a smaller scale of business activity, the impact of the environment and the specificity of processes taking place within the company do not allow to draw simple conclusions about the causes and the course of growth and development processes. In the author's opinion, it is important to focus on entrepreneurial behaviour at a particular stage of the firm's functioning. Economic practice indicates that both in the initial phase of their operation and in the subsequent phases, small businesses may undergo periods of a deteriorated condition, i.e. the deterioration of the parameters achieved by the firm, which is evident in its stagnation that often transforms into the process of reduction in the firm's market share, its size and impact on the market (including its competitive position).

The aim of the paper is to show types of entrepreneurial behaviour which should be trigged during periods of deterioration of small firms' condition.

In order to achieve the objective, the following hypotheses were adopted:

H1: Entrepreneurs identify symptoms of deterioration in the condition of their firms too late, and therefore take corrective actions too late.

H2: Effective management of a small firm in the period of deterioration in its condition requires the initiation of the entrepreneurial process and/or its deliberate continuation.

In order to verify the hypotheses adopted, a theoretical analysis of the problem based on a literature review and an analysis of the results of empirical research were conducted.

The study concerned the causes and symptoms of economic failure identified along the trajectories of this phenomenon. The paper uses selected parts of the study related to the non-occurrence of entrepreneurial behaviour or errors in this behaviour identified in the surveyed companies. The entire study was conducted based on the analysis of 57 case studies, including 32 case studies carried out among former entrepreneurs of liquidated micro and small firms.

The literature review covers a series of issues related to the field of entrepreneurship, management of small firms and their economic failures.

The section concerning the entrepreneurial process as a factor in reducing the risk of economic failure focuses on the description of the ways of preventing unintended economic failures of small firms based on the entrepreneurial process.

The section on material and methods presents the results of studies available in the literature and the results of the author's own research. 
The section concerning results and discussion presents the research findings in conjunction with the possibility of their use by entrepreneurs. Further research opportunities and their limitations are indicated.

Conclusions contain the author's own conclusions and recommendations for entrepreneurs and representatives of business environment institutions.

\section{LITERATURE REVIEW}

\section{The Entrepreneurial Process as a Factor in the Creation and Development of Small Firms}

Due to the fact that entrepreneurship does not occur at once but is a process that has its beginning and subsequent phases, it is difficult to systematise (Piasecki, 2001, pp. 2528). The entrepreneurial process is often dynamic, unique, intermittent, variable and initiated by the individual's will. It is therefore dependent on many variables and characterised by high sensitivity to changes in their value. Based on analyses of the characteristics of entrepreneurship perceived from the process approach perspective presented by various authors, it can be seen that the most important is identifying and making use of opportunities, or possibilities, which in subsequent phases leads to the creation of a new venture.

Among the many studies of the process of business creation, the model combining separate actions into an overall concept of creating a new organisation developed by Gartner should be emphasised (Gartner, 1985, p. 698).

On the basis of the four-dimension model, interactions between the initiating individual, the environment, the organisation and the process can be observed.



Figure 1. Gartner's model

Source: (Gartner, 1985, pp. 696-706).

1. The individual that is involved in the process (analysed in terms of psychological attributes, such as the need for achievement, willingness to take risks).

2. The environment (a situation in which the individual finds himself or herself and which affects him or her - the availability of capital and other resources, suppliers, etc.).

3. The organisation (the type of business).

4. The process (the type of actions taken - accumulation of resources, production, organisation building). 
According to Gartner, the presented model is an instrument for analysing different paths in the creation of new ventures, showing the complexity of the phenomenon and the interactions between the various dimensions of the model.

In the model proposed by Shane (2003, p. 10), the entrepreneurial process begins with the identification of business opportunities, i.e. situations in which resources can be recombined and used in a way which brings profits. Entrepreneurship is understood in this model as a relationship between the individual and the opportunity. It is a directed process which occurs in a certain order, which may be non-linear.



Figure 2. Shane's model

Source: (Shane, 2003, p. 11).

The process of identifying opportunities is individual in its nature and occurs in different ways depending on the available information and beliefs of the entrepreneur. Access to information is shaped by many factors, such as life experience, networking, education, and the manner of search for information. Despite having access to the same information, not everyone is able to identify emerging opportunities. Individual characteristics of a given person affect the manner of identifying and making use of opportunities. Table 1 presents demographic and psychological factors that, according to Shane, have an impact on the use of entrepreneurial opportunities.

Another depiction of the entrepreneurial process is the model proposed by Timmons and Spinelli (2004), which shows the most important components of this process (Fig. 3 ).

The presented model shows that there should be a balance and a mutual fit between the presented elements, i.e. opportunities, resources and the team. First, the entrepreneur must recognise the market opportunity which underpins the whole process. Its perception prompts the individual to take action through which it will be possible to make use 
of this opportunity. For this purpose, the entrepreneur creates a team and acquires the necessary resources.

Table 1. Factors influencing the use of entrepreneurial opportunities

\begin{tabular}{|l|l|}
\hline \multicolumn{1}{|c|}{ Demographic factors } & \multicolumn{1}{|c|}{ Psychological factors } \\
\hline $\begin{array}{l}\text { Education - knowledge and skills that help in } \\
\text { the identification of opportunities }\end{array}$ & Extraversion \\
\hline $\begin{array}{l}\text { Work experience - a richer professional life re- } \\
\text { sults in the accumulation of a greater amount } \\
\text { of information that is needed to identify oppor- } \\
\text { tunities }\end{array}$ & Intuition \\
\hline \multirow{2}{*}{$\begin{array}{l}\text { Marital status - married people have more } \\
\text { courage to take risks }\end{array}$} & $\begin{array}{l}\text { The need for achievement - people with } \\
\text { a strong need for achievement are more likely } \\
\text { to take advantage of emerging opportunities, } \\
\text { as it is connected with facing new challenges }\end{array}$ \\
\hline \multirow{2}{*}{$\begin{array}{l}\text { Entrepreneurial experience - observation of } \\
\text { other entrepreneurs (e.g.: family members) } \\
\text { teaches entrepreneurial behaviour }\end{array}$} & $\begin{array}{l}\text { Propensity to take risks - the willingness to } \\
\text { take risks or act in conditions of uncertainty is } \\
\text { conducive to making use of opportunities. } \\
\text { This personal feature is related to tolerance of } \\
\text { ambiguous and unclear situations }\end{array}$ \\
\hline $\begin{array}{l}\text { Age - older people have more information re- } \\
\text { sources but are less willing to take risks }\end{array}$ & $\begin{array}{l}\text { The need for independence - people used to } \\
\text { taking independent actions make use of en- } \\
\text { trepreneurial opportunities more often }\end{array}$ \\
\hline $\begin{array}{l}\text { Social position - a higher social status increases } \\
\text { the chances of taking advantage of opportuni- } \\
\text { ties, as it is easier for these individuals to con- } \\
\text { vince others to their ideas, in addition, they also } \\
\text { often have numerous, valuable contacts }\end{array}$ & $\begin{array}{l}\text { Control - inner conviction about the possibil- } \\
\text { ity of having an impact on the environment in } \\
\text { which onerates helps in taking advantage } \\
\text { of opportunities }\end{array}$ \\
\hline \multirow{2}{*}{\begin{tabular}{l} 
Confidence in one's own abilities \\
\cline { 2 - 2 } self-confidence, optimism and conviction in \\
the righteousness of one's beliefs allow the \\
exploitation of entrepreneurial opportunities
\end{tabular}} \\
\hline
\end{tabular}

Source: The author's compilation based on (Shane, 2003, pp. 45-59).

\section{Opportunities}

The entrepreneurial process begins with an opportunity. The recognition of this opportunity is rooted in creativity which is an attribute that the entrepreneur and the team share. However, not every good idea translates into a unique opportunity. Timmons and Spinelli indicate that for every 100 ideas presented to investors, whether in the form of a business plan or a general proposal, fewer than four receive funding (Timmons \& Spinelli, 2004, p. 111). Therefore, the ability to quickly estimate potential effects of an idea and to make the decision of how much time and resources to dedicate to it is an important skill of the entrepreneur and the investor. 




Figure 3. Entrepreneurial process

Source: (Timmons \& Spinelli, 2004, p. 110).

\section{Resources}

According to Timmons and Spinelli (2004), it is not essential to have all the necessary resources, especially capital, to make a venture successful. Money follows high potential opportunities, perceived and promoted by a strong management team. The authors cite the concept of bootstrapping as a way to create entrepreneurial companies since this concept allows to develop a significant competitive advantage. Bootstrapping is a philosophy of business operations, especially in the early stages of the company's development, based on the use of internal sources of funding with cost reduction accompanied by the rapid introduction of the venture into the market to generate revenues. At a later stage, further improvement of the product occurs. Appropriate management of working capital cycle (a short-cycle of receivables turnover along with the maximum extension of terms of payment) is an important principle in this respect.

\section{Team}

A new venture requires an entrepreneurial leader who has such personal qualities as the ability to quickly learn and teach others, flexibility, the ability to face adversity, as well as honesty and integrity. The ability and skills to acquire other key members of the team and 
then build this team are one of the most desirable capabilities which investors look for. When creating a team, attention must be paid to professional qualifications, motivation and commitment, self-reliance, teamwork skills and creativity.

To sum up, the entrepreneurial process is:

- driven by opportunity,

- based on an entrepreneurial leader and an entrepreneurial team,

- creative and resource-conserving,

- dependent on the fit and balance between resources and needs,

- integrated and holistic.

The above-mentioned considerations are used in the discussion on entrepreneurship in the period of conscious creation of the future growth and development of the firm by the entrepreneur. At this point, it is worth drawing attention to the role of business model in this process, which is increasingly often indicated by the authors. A model which is practical, comprehensible and possible to independently design and build by the entrepreneur. In addition, it is easier to build a strategy comprising the stage of strategic analysis, strategic planning, strategy implementation and control based on a business model. Regrettably, this strategic orientation is not often used by small firms. Many small firms believe that strategies are used in medium-sized or large companies. In this respect, it is worth noting that modern approaches to organisational strategy include a clear focus on (compare: Romanowska, pp. 95 - 103, in Krupski, 2005):

- company size,

- organisational solutions used in the company (e.g.: radial or simple organisational structure),

- outsourcing relations,

- forms of cooperation with other organisations, etc.

This is reflected in research and papers on the subject. In recent years, there are new perspectives on the development of strategies of organisations that operate in an everchanging, turbulent environment. Concepts of organisations operating on the edge of chaos, without clearly defined objectives, experimenting and looking for optimal solutions (Brown \& Eisenhardt, 1998, pp. 7-9), taking advantage of opportunities and formulating simple rules instead of strategic goals (Eisenhardt \& Sull, 2001, pp. 109-110) are an attempt to respond to challenges presented by a turbulent environment. According to Krupski, strategies for organisations operating in a turbulent environment should be flexible and geared towards making use of opportunities, which can be achieved through (Krupski, 2009, pp. 99-100):

- resignation from the description of the firm's future in terms of product and market in favour of the description of the strategy in terms of resources that determine the effective use of opportunities,

- the assumption that the longer the time horizon, the more issues concerning the acquisition and use of resources should be included in the strategy,

- the assumption that the strategy should include a plan to create the conditions for exploiting opportunities or simple rules of the organisation's functioning,

- the assumption that the only form of strategy in terms of product and market is one characterised by a dynamic nature in the form of scenarios or options. 
At the same time, as pointed out by the author of this concept, uniqueness and originality of tangible resources is rather difficult to achieve (apart from few exceptions, they are usually widely available), whereas unique combinations of intangible resources can strengthen the firm's competitive position. Due to their potential originality, the following resources have been identified (Krupski, 2007, pp. 14-15):

- knowledge, skills and talents of employees (specialised, elite, original),

- attitudes and behaviour of employees, motivations and other elements of organisational culture,

- privileged relations with the environment, formalised - licences, certificates,

- privileged relations with the environment, informal - personal contacts based on trust and loyalty, etc.,

- industry technologies - e.g.: patents,

- information technology - proprietary software,

- the company's own natural resources or resources at its disposal,

- location,

- the firm's image - trademarks, history, reputation,

- sources of funding,

- routines, inter-organisational solutions.

The results of research conducted by Krupski (2007) have shown that for small and micro firms the most valuable, rare and difficult to reproduce are informal privileged relations with the environment.

As follows from the previous considerations, the person of the entrepreneur is inextricably linked with the analysis of the functioning of small businesses. This applies both to business success as well as failure. The subject of deterioration in the condition of the firms analysed in the paper should be seen in relation to the cause(s) of the deterioration of their business parameters and the effects that this situation can have in the future. As a result of errors on the part of entrepreneurs, symptoms of deterioration in the economic situation of the company appear. This period may be transient and manifest itself only as a short-term decline or stagnation of the firm's position in the market (its market share), a reduction in its size, etc. However, in many cases, this period represents a threat to the survival of the company on the market. As a result, the company may find itself on the trajectory of business failure (Ooghe \& De Prijcker, 2006, pp. 12-13; Crutzen, 2010).

\section{The Entrepreneurial Process as a Factor in Reducing the Risk of Economic Failure}

The literature describing consequences of long-term deterioration in the condition of small businesses comprises models that indicate areas and related causes of the entry of a small firm onto the trajectory of economic failure. The areas include: the company's policy and resources, the characteristics of the entrepreneur and the characteristics of the enterprise.

The company's policy and resources (its strategy, finances, operational activities, management system, tangible and intangible resources, etc.) are associated with the person of the entrepreneur (the entrepreneur's motivation, skills, abilities, character traits, etc.) and with the characteristics of the enterprise (the period of its development, sector, size, etc.) They form, along with the environment, the real source of the given firm's entry onto the trajectory of economic failure. The deterioration of the condition of the firm, which 
should be a warning sign for the entrepreneur (Ropęga, 2013, pp. 59-60), may be the beginning of this road.

Analysing the course of economic failures of small businesses, one can come to the conclusion that action is needed to identify causes of the deterioration in their condition (including root causes), as well as symptoms and manifestations of business crisis (Piasecki, 2012, p. 6).

Given these components, it can be noted that the person of the entrepreneur plays an important role in this respect. The entrepreneur becomes both the main initiator of the creation of the company and the main person responsible for causing its economic failure. The entrepreneur often participates in events leading to the deterioration in the condition of the small business and its future economic failure.

Thus, the literature provides recommendations to prevent unintended economic failure of small firms, directly related to the behaviour of the entrepreneur. For example, in Poland, based on a recommendation of the Ministry of Development (formerly the Ministry of Economy), the New Opportunity Policy (NOP) programme was created, containing, among others, the following recommendations:

1. improvement of access to information and knowledge sources for entrepreneurs,

2. improvement of the economic, legal, political and technological system shaping the conditions for small firms' operations,

3. introduction of changes in the characteristics, behaviour and attitudes of managers of small firms.

In the context of the undertaken subject, it seems particularly relevant to seek to increase the importance of entrepreneurial traits, behaviour and attitudes in the decisionmaking process related to managing a small firm in the period of deterioration in its condition and its potential entry onto the trajectory of business failure.

Table 2. Basic "inherent" problems specific to small businesses

\begin{tabular}{|c|c|}
\hline $\begin{array}{l}\text { Determinants of firm's } \\
\text { success or failure }\end{array}$ & Characteristics \\
\hline $\begin{array}{l}\text { The person } \\
\text { of the owner-manager }\end{array}$ & $\begin{array}{l}\text { Key decisions about the firm are taken usually by one person - the } \\
\text { owner-manager. Personal qualities and attitudes of the owner-man- } \\
\text { ager determine how a small business is managed and the likelihood } \\
\text { of its success or failure. The quality of management in the firm de- } \\
\text { pends on what kind of experience and skills its owner has. }\end{array}$ \\
\hline Isolation & $\begin{array}{l}\text { Owners of small businesses do not have the opportunity for mutual } \\
\text { discussion or sharing problems, as is the case in larger companies. } \\
\text { A lack of sufficient knowledge and information about the environ- } \\
\text { ment. }\end{array}$ \\
\hline Lack of time & $\begin{array}{l}\text { Focusing key functions in one hand leads to a lack of time and work- } \\
\text { ing under very high pressure, which affects the quality of manage- } \\
\text { ment. }\end{array}$ \\
\hline
\end{tabular}

Source: own compilation based on (Argenti, 1976, pp. 123-125), (Jennings \& Beaver, 1995, pp. 185-200), (Peacock, 2000, pp. 6-7), (Gumpert \& Boyd, 1984, pp. 18-24), (Larson \& Clute, 1979, pp. 35-43).

Many researchers that study the deterioration of the market position and failures of small businesses indicate that the person of the owner-entrepreneur is the key factor 
determining the success or failure of the given company ${ }^{1}$ Argenti determines these factors as "inherent" flaws present in the company. They include: (i) the characteristics of the owner-manager (ii) isolation, (iii) a lack of time. The table 2 presents the description of the above-mentioned factors (Argenti, 1976, pp. 123-125).

The current trend in research related to the person of the entrepreneur, mainly based on the human capital theory (Becker, 1993, p. 59), suggests that the higher the quality of human capital in terms of personal attributes and skills of the entrepreneur, the higher the chance of the company's survival. Among the major factors affecting the reduction of the risk of failure, the following ones come to the fore: experience in business and management (Brüderl, Preisendörfer, \& Ziegler, 1992, pp. 231-233; Pasanen, 2005, p. 103), professional experience in the industry (Preisendorfer \& Voss, 1990, pp. 123-124; Carter, Gartner, Shaver \& Gatewood, 2003, pp. 33-34; Brüderl et al. 1992, pp. 231-233), and education (Brüderl et al. 1992, pp. 231-233; Bates, 2005, p. 8).

\section{MATERIAL AND METHODS}

For the purpose of the paper, a theoretical analysis of the problem based on a literature review and an analysis of the results of empirical research were conducted. The author identified in the literature the results of research on the process of decision-making of entrepreneurs. The studies were divided according to the following criteria: entrepreneurs' decisions in relation to their motivation for undertaking business activity and entrepreneurs' decisions in relation to their character traits and behaviour. The following factors influence the behaviour and attitudes of entrepreneurs in the periods of deterioration in the condition of their firms.

\section{Motivation for Undertaking Business Activity}

According to Smallbone, motives for undertaking business activities may have an impact on the future success of the given venture (Smallbone, 1995, p. 12). Greater chances of survival are observed in the case of companies founded by the entrepreneurs who saw opportunities arising from the environment and were prompted to establish their firm than in the case when their motivation was solely to become self-employed to avoid unemployment.

Storey (1994, pp. 91-99) classifies these types of motivation as positive (pull factors) and negative ones (push factors) ${ }^{2}$. Positive motivation results from "the need to become an entrepreneur" (Wasilczuk, 2005), an informed choice concerning a better alternative, as well as the perception of an opportunity for a successful venture (Bacławski, Koczerga \& Zbierowski, 2005, pp. 11-12) ${ }^{3}$. The factors such as the need for independence, the need

\footnotetext{
${ }^{1}$ Large companies are generally managed by a team of professional managers, hence the impact of individual personal characteristics on the effectiveness of the company's operations is smaller, in contrast to small firms where the decision-making process is often dominated by one person - the owner.

${ }^{2}$ In other words: opportunity factors or necessity factors (Bacławski et al., 2005, pp. 11-12; Verheul et al. 2010).

${ }^{3}$ Giacomin et al. (2007, p. 11) indicate the following groups of pull factors: factors related to market opportunities, factors related to the improvement of one's material status. Carter et al. $(2003$, p. 20) provide the following classification of motivation categories: innovation (the desire to introduce a new product or service), independence (freedom to control one's own time, more flexibility between working time and time devoted to the family),
} 
to succeed in running one's own business or a dream of a particular type of business (Orhan \& Scott, 2001, p. 238), as well as the desire for filling a market niche and personal development (Carter et al. 2003, p. 37) contribute to an increase in the growth potential and higher chances of survival more than negative motives (Bacławski et al. 2005, pp. 1418).

The necessity (compulsion) to set up a business is mainly due to the situation in the labour market. According to the authors of Global Entrepreneurship Monitor (Bacławski et al., 2005, p. 17), negative motivation is based on the assumption that long-term high unemployment or the threat of losing a job stimulate the desire for economic independence ${ }^{4}$, i.e. the creation of businesses is a reaction to social difficulties and little chance in the labour market ${ }^{5}$. Giacomin at el. $(2007$, p. 12) also include pressure from relatives to continue the family business in the group of negative factors.

\section{The Firm's Survival}

In the research conducted by Watson, Hogarth-Scott, and Wilson (1998, p. 232), such motives to establish business activity as the need for independence, dissatisfaction with the current job, or the utilisation of creative skills were more often indicated by entrepreneurs who continued business activity than by those who have suffered economic failure. The research conducted by Hall (1994) shows that a greater propensity for failure was observed in companies founded by entrepreneurs who were forced to do so, e.g.: due to the reduction of employment, than in companies where "positive" motives were the reason for taking up business activity, e.g.: the desire to increase earnings, or the need for independence.

\section{The Entrepreneur's Character Traits}

The entrepreneur's character traits can also have a significant impact on decision-making in the firm, thus on the results achieved, and in consequence, on its business success or failure. Larson and Clute $(1979$, p. 37$)$ point to such personal features of the entrepreneur that are conducive to failure: relying on one's own taste and opinion in the product selection, making decisions based solely on intuition and emotions and not on objective premises, not taking advice from external advisors, inflexibility in decision making, as well as focusing on the past and ignoring future events. In addition, the following characteristics

\footnotetext{
recognition (in the eyes of the family and friends, a higher position in the community), roles (imitating others), financial success, and self-realisation. Birley and Westhead (1994) and Verheul et al. (2010) make similar classifications.

${ }^{4}$ This is a reference to Knight's theory (quoted after Storey, 1994, pp. 62-63), according to which people make a choice in terms of professional activity between: being unemployed, being employed or being self-employed. ${ }^{5}$ The push factors related to the situation in the labour market include: unemployment, unsatisfactory earnings, dissatisfaction with the current job, the difficulty with reconciling professional and family roles (Verheul et al., 2010, Giacomin et al., 2007). The last factor is related particularly to women who often have difficulty reconciling employment with the upbringing of children (compare: Bacławski et al., 2005, Carter et al. 2003). According to the research for Global Entrepreneurship Monitor, in 2004, among 34 countries participating in the project, on average $75.2 \%$ of the ventures were undertaken as a result of an emerging opportunity, $20.9 \%$ out of necessity and $3.9 \%$ for other reasons. In Poland, ventures undertaken by choice amounted to $64.7 \%$, while the ones undertaken out of necessity to $35.3 \%$. Women are more likely than men to start companies out of necessity, and in terms of the age of entrepreneurs, the largest percentage of people engaged in business activity because of push factors was recorded among the 55-64 age group - 54.5\% (Bacławski et al., 2005, pp. 16-17).
} 
may be also mentioned: too low or too high propensity for risk taking (Ibrahim and Goodwin, 1986), a lack of charisma (O'Neil \& Duker, 1986) or an autocratic and dominant character (Argenti, 1976). To understand why some entrepreneurs are successful and others fail, the combination of three elements should be analysed: personality traits, knowledge and experience along with professional skills (Ropęga, 2013, p. 60). The likelihood of success or failure does not depend on a certain set of attributes, but on the infinite variety of combinations in which the particular person's positive attributes can outweigh the negative traits.

Based on the theoretical analysis of the problem, the results of published studies and the discussion concerning the issue, the author conducted his own research. For the purpose of the paper, the author formulated two research hypotheses:

H1: Entrepreneurs identify symptoms of deterioration in the condition of their firms too late, and therefore take corrective action too late.

H2: Effective management of a small firm in the period of deterioration in its condition re-quires the initiation of the entrepreneurial process and/or its deliberate continuation.

The above-presented hypotheses were included in the methodology of the study.

The study concerned the causes and symptoms of economic failures identified along the trajectories of this phenomenon. The entire study was conducted based on the analysis of 32 case studies carried out among the former entrepreneurs of micro and small firms in the period from 01.01.2006 to 31.12.2011. Their addresses were extracted from the REGON (National Business Registry) database. As a result of the verification, a group of potential addresses, which could also be places of residence of the entrepreneurs, was established. The criteria for the selection included: the contact made with the former owner of the liquidated company, obtaining his or her approval to conduct research, the verification of the actual liquidation of economic activity, and conducting the full range of study. The research was conducted throughout the country. The method of the selection of companies for the study was purposeful.

The ancillary form used in the study included the following issues:

- identification of the number of employees at the time of liquidation and a year before the liquidation,

- predominant type of activity (based on the Polish Classification of Activity),

- the firm's territorial area,

- number of the owners,

- age of the owners,

- the owner's experience in conducting business activity,

- motives for undertaking business activity,

- internal causes of failure, including the area of: strategy, expansion, planning and financial management, human resources, marketing, innovation, production/services and operational activities,

- external causes,

- access to sources of financing,

- effective prevention of economic failure. 
The paper uses selected parts of the study related to the non-occurrence of entrepreneurial behaviour or errors in this behaviour identified in the surveyed companies. In the course of the study, financial and non-financial information was collected. 18 entrepreneurs made the financial documentation of their firms available, in the other cases, the assessment of the economic and financial standing of the firms was carried out in a descriptive manner by their owners, using the characteristics presented by Argenti. Changes in the condition of the firm in time were characterised as follows:

- Poor condition of the firm - the firm's results are worse than its major competitors' and the industry average; the firm's financial results or cash flows are negative;

- Good condition of the firm - the results are comparable with its competitors or the industry average, profits are made and positive cash flows are recorded;

- Excellent condition of the firm - the results surpass those achieved by its competitors, an increase in financial results compared to previous periods is observed;

- Fantastic condition of the firm - rarely achievable, characterised by almost unreal results in comparison with the industry or its competitors.

As a result of the research conducted, the verification of trajectories of economic failure in small businesses presented in the literature was carried out. In the course of analysing the results of research, an additional, unique trajectory identified in the surveyed companies was isolated. Its identification was due to the specificity of the trajectory course in 7 of the 32 firm surveyed. Their share was so large that the author introduced the trajectory of LACK OF SELF-CRITICISM AFTER RAPID, APPARENT GROWTH OF THE COMPANY into the existing classification. As a result, the study highlights 6 trajectories of business failure (TBF).

Table 3. The number of cases identified in the individual trajectories of economic failure

\begin{tabular}{|l|c|}
\hline \multicolumn{1}{|c|}{ Type of trajectory of business failure (TBF) } & $\begin{array}{c}\text { Number } \\
\text { of cases }\end{array}$ \\
\hline (TBF 1) FAILED START-UP & 4 \\
\hline (TBF 2) GROWING COMPANY UNDER UNSTABLE MANAGEMENT & 8 \\
\hline (TBF 3) LACK OF SELF-CRITICISM AFTER RAPID, APPARENT GROWTH OF THE COMPANY & 7 \\
\hline (TBF 4) LACK OF SELF-CRITICISM AFTER REAL, RAPID GROWTH OF THE COMPANY & 5 \\
\hline (TBF 5) MATURE APATHETIC COMPANY & 6 \\
\hline (TBF 6) EXCESSIVE INTERNAL CONSUMPTION & 2 \\
\hline
\end{tabular}

Source: own compilation.

The replies provided by the respondents were characterised by a large degree of subjectivity on the part of the former business owners - managers. In the course of the study, the author sought to verify the respondents' answers with great care, asking questions related to the context of actions and decisions undertaken by the business owners. A great deal of attention was devoted to the references to possible strategies of the surveyed firms and the assessment of the environment on the part of the former owners - managers related to a strategic approach. Despite the author's doubts about the objectivity of the responses of the former owners in relation to their role in the process of economic failure, their arguments were accepted. However, the descriptions of individual trajectories contain the author's conclusions concerning the management process in the analysed cases. 
Due to the aim of the paper and the research hypotheses under verification, the following components indicating the deterioration in the condition of the firm along individual trajectories (based on the division presented in Table 3) were identified: specific threats, systematic threats, internal causes, external causes, non-financial symptoms, financial symptoms, and the course of the crisis.

The above-presented components were analysed in relation to the activities of the entrepreneurs who provided an assessment of their own efforts to initiate the entrepreneurial process and/or continue it in a deliberate manner.

As a result of the study, the responses were obtained that indicated a lack of understanding of the entrepreneurial process and its application.

\section{RESULTS AND DISCUSSION}

The qualitative study conducted by the author of the paper has confirmed a lack of entrepreneurial attributes, behaviour and attitudes in people that have concluded economic activity as a result of business failure. The author's research indicates a correlation between the lack of entrepreneurial behaviour and individual trajectories of economic failure. Considerations regarding the phenomenon of economic failure of small businesses can be transposed into the factors that restrict the entrepreneurial process, based on the components of the model proposed by Timmons and Spinelli (2004). Limitations existing in relation to the model indicated in the first part of the paper are related to the occurrence of threats in place of the existing opportunities. The component of the entrepreneurial process in the form of the team may be also deprived of its leader or based on inappropriate relations between individual employees of small firms. In terms of the discussed model, shortcomings or wrong actions in individual components can be seen in practically all the six trajectories. As a result, the lack of entrepreneurial process identified was manifested in:

- Lack of response on the part of entrepreneurs to opportunities emerging in the environment - virtually all the surveyed ex-entrepreneurs could not point out any clearly identified opportunities that emerged at the time when the company perceived its deteriorating condition and entered the trajectory of business failure.

- Lack of response to threats emerging in the environment - among the surveyed entrepreneurs only six took action related to a real assessment of the risks arising from the micro-environment (creditors' claims, loss of key customers, loss of competitive advantages, etc.) and the macro-environment (adapting to changing regulations, responding to changes in exchange rates, changes in the market in terms of export/import, or changes in the prices of raw materials, etc.).

- The response to threats emerging in the environment was late/or inadequate to meet the needs. As a result, the firm failed to respond adequately to the threat. The "escape by going forward" often cited in the literature (Piasecki 2012) was used as a way to counteract the situation.

- Lack of entrepreneurship also occurred in the area of resources. The study included both intangible and tangible resources. Most of the respondents focused on the limitations of tangible resources in the form of fixed and working assets, a lack of access to resources resulting from cash shortage, the loss of access to tangible resources and 
their inability to acquire new (alternative) resources. Only three respondents among the ex-entrepreneurs indicated the inability to use their own intellectual resources in the course of events initiated by the deterioration in the firm's condition. In their opinion, it was a fundamental error, as it did not allow them to diagnose the cause of the deterioration in the firm's condition and resulted in an inappropriate reaction to the situation. The respondents did not indicate the existence of a relationship between the lack of tangible resources and the mismanagement of the acquisition of these assets by the entrepreneur. They also did not acknowledge their own ignorance concerning different forms of financing of the firm's operations or forms of support. Also, there were no indications of a formal attempt to prepare the company that was at risk of failure to obtain such resources, e.g.: restructuring plans.

- No active manifestations of entrepreneurship in the area of team building were seen in the 29 analysed cases. This was the result of both a lack of employees in the period of the deterioration of business performance and a lack of focus of the managers of the surveyed companies on team building and development. Most frequently indicated were conflicts between employees and the entrepreneur (the search for a new job during working hours, prolonged absenteeism, absence during the activation of the market for the sake of seasonal work - employees did not perform their professional duties in the company as they undertook seasonal work in construction, agriculture, etc.) and conflicts between employees (obstruction of the performance of official duties, theft, misrepresentation, etc.).

As a result of the deterioration or non-occurrence of entrepreneurial behaviour in the indicated areas, the entrepreneurial process could not take place or it proceeded in an inappropriate manner. Thus, changes are necessary to create a basis for the reduction of threats to business operations.

A lack of creativity, leadership, communication and teamwork is apparent in the analysed cases. Especially during the company's entry onto the trajectory of business failure, it is an additional factor limiting the possibility of counteracting the occurrence of such a situation.

\section{CONCLUSIONS}

The existing solutions describing countermeasures of economic failure show the importance of the strategic orientation in the process of quick identification of warning signs of deterioration in the firm's condition and the need to take swift preventive action. The assumptions in the model of counteracting the phenomenon of economic failure include the need for the speedy identification and analysis of the risk of the occurrence of such a situation, the identification of its causes and symptoms, and - as a result - the development of preventive measures. According to the author, one of the key factors affecting the survival of small businesses in the period of deterioration of their condition is the initiation of the entrepreneurial process and/or its deliberate continuation. It seems quite natural to base the components of this process on the existing support tools for entrepreneurs that are at risk of economic failure. Therefore, the effective implementation of the principles of the existing assistance programmes, for example, the New Opportunity Policy, is recommended. According to the author, the main factor initiating a conscious process of 
strategic orientation in this field is education in the use of entrepreneurship in the modern economy.

The information presented in the results of the research can significantly expand knowledge on the functioning of small firms and the factors causing their entry onto the trajectory leading to economic failure. It has been found that certain factors and processes can affect the formation of erroneous spiral, thus in-depth studies of the process of economic failure are very important.

The results may be useful for entrepreneurs as well as for institutions supporting entrepreneurship and the development of small and medium-sized enterprises.

The research results are based on qualitative case study research. Further studies on a larger scale can help to clarify the factors of failure, and studies of motivation to undertake business activity (push and pull factors) as well as their impact on economic failure of small firms are also an interesting subject worth exploring.

\section{REFERENCES}

Argenti, J. (1976). Corporate Collapse, McGraw-Hill, Berkshire.

Bacławski, K., Koczerga, M., \& Zbierowski, P. (2005). Studium przedsiębiorczości w Polsce w roku 2004, GEM, Fundacja Edukacyjna Bachalski i Krzysztof Bacławski, Poznań.

Bates, T. (2005). Analysis of Young, Small Firms that Have Closed: Delineating Successful from Unsuccessful Closures. Journal of Business Venturing, 20, 343-358.

Becker, G. S. (1993). Human Capital: A Theoretical and Empirical Analysis, with Special Reference to Education, The University of Chicago Press, Chicago.

Birley, S. \& Westhead, P. (1994). A Taxonomy of Business Start-up Reasons and Their Impact on Firm Growth and Size. Journal of Business Venturing, 9, 7-31.

Brown, S.L., \& Eisenhardt, K.M. (1998). Competing on the Edge: Strategy as Structural Chaos, Harvard Business School Press, Boston.

Brüderl, J., Preisendörfer, P. \& Ziegler, R. (1992). Survival Chances of Newly Founded Business Organizations. American Sociological Review, 57(2), 227-242.

Carter, N.M., Gartner, W.B., Shaver, K.G., \& Gatewood, E. J. (2003). The Career Reasons of Nascent Entrepreneurs. Journal of Business Venturing, 18(1), 13-19.

Crutzen, N. (2010). Essays on the Prevention of Small Business Failure: Taxonomy and Validation of Five Explanatory Business Failure Patterns, [in:] CeFiP-KeFiK Academic Awards 2009, De BoeckLarcier, Bruxelles.

Eisenhardt, K.M., \& Sull, D.N. (2001). Strategy as Simple Rules. Harvard Business Review, 79 (1), 106116.

Gartner, W.B. (1985). A Conceptual Framework for Describing the Phenomenon of New Venture Creation. Academy of Management Review, 10(4), 696-706.

Giacomin, O., Guyot, J.-L., Janssen, F., \& Lohest, O. (2007). Novice Creators: Personal Identity and Push Pull Dynamics, "CRECIS Working Paper", 7, Center for Research in Change, Innovation and Strategy, Louvain School of Management.

Gumpert, D.E., \& Boyd, D.P. (1984). The Loneliness of the Small-business Owner, Harvard Business Review, November-December, 18-24.

Hall, G. (1994). Factors Distinguishing Survivors from Failures amongst Small Firms in the UK Construction Sector. Journal of Management Studies, 31(5), September, 737-760.

Ibrahim, A.B., \& Goodwin, J. R. (1986). Perceived Causes of Success in Small Business. American Journal of Small Business, Fall, 41-50.

Jennings, P.I., \& Beaver, G. (1995). The Managerial Dimension of Small Business Failure. Journal of Strategic Change, 4, 185-200. 
Krupski, R. (2005). Planowany czy nieplanowany rozwój małych firm. Co z teorią zarządzania strategicznego. Przeglad Organizacji, 3, 15-18.

Krupski, R. (2007). Identyfikacja ważnych strategicznie zasobów przedsiębiorstwa w świetle badań empirycznych. Zarzqdzanie - kontekst strategiczny, kulturowy i zasobowy. Prace Naukowe Akademii Ekonomicznej we Wrocławiu, 1187, 13-18.

Krupski, R. (2009). Ewolucja rozumienia strategii organizacji, [in:] J. Prońko (Eds.), Ludzie - Jakość Organizacja. Miscellanea Oeconomicae. Studia i Materiały Wydziału Zarzqdzania i Administracji Uniwersytetu Humanistyczno-Przyrodniczego Jana Kochanowskiego w Kielcach, 13(2), 93-102.

Larson, C.M., \& Clute, R.C. (1979). The Failure Syndrome. American Journal of Small Business, 4(2), 35-43.

O'Neill, H.M., \& Duker, J. (1986). Survival and Failure in Small Business. Journal of Small Business Management, 24, January, 30-37.

Ooghe, H., \& De Prijcker, S. (2006). Failure Process and Causes of Company Bankruptcy: a Typology, Working Paper, Universiteit Gent, 1-43.

Orhan, M., \& Scott, D. (2001). Why Women Enter into Entrepreneurship: An Exploratory Model. Women in Management Review, 16( 5/6), 232-244.

Pasanen, M. (2005). Tracking Small Business Failure Factors and Trajectories, Challenges in Entrepreneurship and SME Research, 2nd Inter-RENT Online Publication, Turku; www.ecsb.org/doc/Inter-RENT\%202005\%20final\%20document.pdf\#page=97 [14.04.2009].

Peacock, R. (2000). Failure and Assistance of Small Firms, www.sbeducation.info/serv03.htm, [29.11.2007].

Piasecki, B. (2001). Ekonomika i zarzqdzanie mała firmq, Wyd. Naukowe PWN, Warszawa-tódź.

Piasecki, B. (2012). Strategie wczesnego ostrzegania i wyjścia z zagrożenia upadkiem, In B. Piasecki (Ed.), Upadek małych firm. Symptomy i strategie wczesnego ostrzegania, Wyd. Uniwersytetu Łódzkiego, Łódź, 113-139.

Preisendörfer, P., \& Voss, T. (1990). Organizational Mortality of Small Firms: The Effects of Entrepreneurial Age and Human Capital. Organization Studies, 11(1), 107-129.

Romanowska, M. (2005). Analiza i planowanie strategiczne w małej firmie, In R. Krupski (Ed.), Zarzadzanie strategiczne. Strategie małych firm. Wyd. Wałbrzyskiej Wyższej Szkoły Zarządzania i Przedsiębiorczości.

Ropęga, J. (2013). Ścieżki niepowodzeń gospodarczych. Redukcja zagrożenia niepowodzeniem jako element strategii małej firmy, Uniwersytet Łódzki.

Shane, S.A. (2003). A general theory of entrepreneurship: The individual-opportunity nexus. Edward Elgar Publishing, Cheltenham.

Smallbone, D. (1995). The Survival, Growth and Support Needs of Manufacturing SMEs in Poland and The Baltic States: Developing a Research Agenda, paper presented to a seminar at University of Lodz, Poland.

Storey, D.J. (1994). Understanding The Small Business Sector, Routledge, London-New York.

Timmons, J.A., \& Spinelli, J. (2004). New Venture Creation: Entrepreneurship For The 21st Century. McGraw-Hill/Irwin.

Verheul, I., Thurik, A.R., Hessels, J., \& van der Zwan, P.W. (2010). Factors Influencing the Entrepreneurial Engagement of Opportunity and Necessity Entrepreneurs. Scales Research Reports H201011, EIM, Business and Policy Research.

Wasilczuk, J. (2005). Wzrost małych i średnich przedsiębiorstw. Aspekty teoretyczne i badania empiryczne, Wyd. Politechniki Gdańskiej, Gdańsk.

Watson, K., Hogarth-Scott, S., \& Wilson, N. (1998). Small Business Start-ups: Success Factors and Support Implications. International Journal of Entrepreneurial Behaviour and Research, 4(3), 217-238. 


\section{Author}

\section{Jarosław Ropęga}

PhD Hab, Departament of Entrepreneurship and Industrial Policy, University of Lodz (Poland). Correspondence to: Dr hab. Jarosław Ropęga, Uniwersytet Łódzki, Katedra Przedsiębiorczości i Polityki Przemysłowej, Wydział Zarządzania, ul. Matejki 22/26, 90-237 Łódź, Poland e-mail: ropega@uni.lodz.pl

\section{Copyright and License}

This article is published under the terms of the Creative Commons Attribution - NonCommercial - NoDerivs (CC BY-NC-ND 3.0) License http://creativecommons.org/licenses/by-nc-nd/3.0/ 